\title{
Antioxidant Effect of Bovine Plasma Proteins Modified via Maillard Reaction on n3 Fortified Beef Patties
}

\author{
Carina Lorena Fernández ${ }^{1,2}$, Ricardo Alejandro Fogar1,2, Mirtha Marina Doval1, \\ Ana María Romero', María Alicia Judis ${ }^{1}$ \\ ${ }^{1}$ Food Industry II Laboratory, Chaco Austral National University (UNCAUS), Presidencia Roque Sáenz Peña, \\ Chaco, Argentina \\ ${ }^{2}$ National Council of Scientific and Technical Investigations (CONICET), Buenos Aires, Argentina \\ Email: carina@uncaus.edu.ar
}

Received 15 February 2016; accepted 27 June 2016; published 30 June 2016

Copyright (C) 2016 by authors and Scientific Research Publishing Inc.

This work is licensed under the Creative Commons Attribution International License (CC BY). http://creativecommons.org/licenses/by/4.0/

c) (i) Open Access

\section{Abstract}

This work aimed to develop a healthier meat product, by improving nutritional properties related to lipid profile, using a Maillard reaction product (MRP) obtained from recycling blood from local slaughterhouses as antioxidant. Soybean oil was used as partial fat replacer and the lipid profile was modified as a decrease in the $\mathrm{n} 6 / \mathrm{n} 3$ ratio (11.59 to 9.50), and atherogenic and trombogenic index (from 0.42 to 0.27 and 0.94 to 0.56 respectively) was observed. Beef patties were added with two MRP levels $(1 \% \mathrm{w} / \mathrm{w}$ and $3 \% \mathrm{w} / \mathrm{w})$. Patties with no antioxidants were used as control and patties containing $0.01 \% \mathrm{w} / \mathrm{w}$ of butylhydroxyanisole (BHA) were used as reference. Oxidative stability of refrigerated vacuum-packed patties was evaluated during 15 days of storage. Results showed 3\% of MRP as the most appropriate concentration to prevent lipid oxidation with inhibition percentages of $75 \%$, and 9 days as the limit time of chilled storage regarding consumers' perceptions.

\section{Keywords}

Meat Industry Waste, Natural Occurring Antioxidants, Lipid Oxidation, Healthier Meat Commodities, Functional Meat Products

\section{Introduction}

Meat is an essential component of a healthy and well-balanced diet, since it is an interesting protein and iron

How to cite this paper: Fernández, C.L., Fogar, R.A., Doval, M.M., Romero, A.M. and Judis, M.A. (2016) Antioxidant Effect of Bovine Plasma Proteins Modified via Maillard Reaction on n3 Fortified Beef Patties. Food and Nutrition Sciences, 7, 671681. http://dx.doi.org/10.4236/fns.2016.78068 
source [1]. However, it usually shows high amounts of saturated fat, which have been closely related to some chronic diseases [2]-[4]. As a result of the scientific evidence, health authorities recommend a reduction of cooked meat products intake or directly to avoid certain meat products [5]. In this regard, beef patties are still consumed world-wide despite of its apparent bad nutritional aspect. Therefore, in recent years great efforts have been exerted in order to develop nutritionally improved meat patties using reformulation strategies, e.g. the substitution of pork back fat with vegetable oils, which has been demonstrated to be a good tool to achieve a healthier lipid profile in these products [6] [7], by decreasing saturated fatty acids (SFA) levels and improving certain nutritional indices, as n6/n3 ratio, atherogenic index (AI) and trombogenic index (TI). The beneficial effect of the partial replacement of animal fat with different vegetable oils has been investigated in numerous meat products such as dry-cured sausages [8], frankfurters [9] and burger patties [10] [11]. Therefore, increasing the polyunsaturated fatty acid (PUFA) content seems to be the most suitable way to improve the lipid fraction of meat products [12]-[14] but this implies a higher susceptibility to oxidative processes, which generate a decrease of the nutritional value of the food, and the formation of potentially toxic compounds [15].

Food industries usually resort to the use of synthetic antioxidants to prevent lipid oxidation, although the scientific evidence of their possible toxic effects and the consumers' preferences for natural products force the meat industry to use naturally occurring antioxidants. In this regard, research works include fruit juices [16], tea extracts [17], residues from the wine industry [18] and different Maillard reaction products such as amino acidsugar reaction products [19] [20], porcine plasma proteins-sugar reaction products [21] and other protein-aldehydes reaction products [22] [23]. The addition of such substances usually darkens the meat product, limiting its use due to the impact on food colour.

On the other hand, blood is an inevitable by-product of the meat industry representing up to $4 \%$ of the live animal weight. Animal blood produced in slaughterhouses represents a problematic waste of the meat industry due to the high volumes generated and its very high pollutant load when discarded directly into the environment [24]. It also has a high protein content (17\%), with a reasonably good balance of amino acids, however, the use of blood in meat processing may mean that the final product is dark in colour [25]. Several studies report the antioxidant properties of bovine blood proteins hydrolysates [26]-[28], but there is not enough information about the use of plasma proteins as a source of amino groups for the Maillard reaction, which is known to provide antioxidant compounds. Previous studies of this research group have demonstrated the antioxidant action of a Maillard reaction product (MRP) obtained by reacting bovine plasma proteins and aldehydes when used in model systems [23], although tests on food products were not conducted.

When using a fat replacer, a careful approach is needed in order to achieve the appearance and technological, rheological and sensory properties required in the food product, thus the aim of this work was to improve the fatty acid profile of beef patties through the partial replacement of animal fat by soybean oil, and to study the effect of a MRP antioxidant, obtained from recycling blood from a local slaughterhouse, on the oxidative stability and colour of beef patties subjected to cooking and chilled storage.

\section{Material and Methods}

\subsection{Chemicals}

Sodium citrate, potassium ferricyanide, trichloroacetic acid (TCA) and ammonium thiocyanate were purchased from Biopack (Argentina). Hexanal, sodium phosphate, butylhydroxyanisole (BHA), ferrous chloride and thiobarbituric acid (TBA) were obtained from Merck (Germany). Ferrozine, ethylenediaminetetraacetic acid (EDTA), boron trifluoride, standard fatty acid methyl esters (Fame 37) and 1,1,3,3-tetramethoxypropanewere provided by Sigma-Aldrich (Germany). Chloroform, methanol, hydroloric acid and ethanol were obtained from Cicarelli (Argentina).

\subsection{Material}

\subsubsection{Raw Material}

Fresh beef meat, pork back fat and soybean oil were obtained from a local market. Bovine blood was kindly provided by Cooperativa Agropecuaria La Union Ldta (Chaco, Argentina).

\subsubsection{Obtaining of Bovine Plasma Proteins (BPP)}

Bovine blood was collected from a local slaughterhouse every two months, starting on February and ending at 
June 2014. In all cases, the provided blood was mixed with sodium citrate $(2.5 \mathrm{w} / \mathrm{w})$ to prevent clotting and refrigerated until use. All collected blood was centrifugated at $2500 \mathrm{~g}$ and $2^{\circ} \mathrm{C}$ during 10 minutes (Hettich Zentrifugen, Rotina 380 R, Germany). The supernatant was refrigerated until use. Protein content was determined by the Biuret method as described by Robson, Goll and Temple [29].

\subsubsection{Obtaining of Aldehydes Mixture by Oxidizing Soybean Oil (SO)}

Soybean oil (SO) (3.5 g) was oxidized in rotary evaporator (Figmay SRL, Argentina) at $80^{\circ} \mathrm{C}$; aldehydes arising were removed by nitrogen flow and collected in Sorensen buffer ( $\mathrm{pH} 7.6)$. Aldehydes content was determined at $265 \mathrm{~nm}$ in a UV-visible Beckman DU 640B, Fullerton, CA, USA spectrophotometer and expressed as mg hexanal/mg soybean oil. Ethanolic solutions of hexanal (1000 to $3000 \mathrm{mg} / \mathrm{L}$ ) were used as standard to prepare a calibration curve. The end of the process was reached after 6 hour of heating, when absorbance measurements remained constant. The aldehydes content achieved was $0.006 \mathrm{mg}$ hexanal/mg soybean oil.

\subsubsection{Preparation of the Maillard Reaction Product (MRP)}

MRP was obtained from the reaction between bovine plasma proteins and aldehydes arising from SO oxidation. Plasma proteins were incubated with aldehydes in a ratio 3.5:1. The mixture ( $\mathrm{pH} 7.6)$ was kept in rotatory evaporator at $80^{\circ} \mathrm{C}$ for $4 \mathrm{~h}$ under moderated agitation $(56 \mathrm{rpm})$. These temperature-time conditions were determined in previous studies [30]. The resultant mixture was lyophilized to obtain the dry product (MRP).

\subsubsection{Manufacture of Traditional and n3 Fortified Beef Patties}

Five types of beef patties were prepared including a control batch manufactured with pork back fat and no added SO. The ingredients per $\mathrm{kg}$ of patty in the basis formulation were as follows: $800 \mathrm{~g}$ meat, $200 \mathrm{~g}$ pork back fat and $20 \%$ sodium chloride. In the formulation of patties manufactured with SO (n3 fortified patties), $50 \%$ of the animal fat was replaced with $100 \mathrm{~g}$ of SO per kg patty.

The experiments were conducted as follows: the $\mathrm{n} 3$ fortified patty formulation was divided into four treatments: 1) control without antioxidant; 2) MRP at 1\% w/w; 3) MRP at 3\% w/w; and 4) $0.01 \% \mathrm{w} / \mathrm{w}$ of BHA as a reference. Patties were formed in Petri dishes to obtain samples of $100 \mathrm{~g}$ each one $(9 \mathrm{~cm}$ diameter and $1.5 \mathrm{~cm}$ thickness). The MRP levels were established in previous studies [22]. According to the limit level allowed, 0.02 $\mathrm{g}$ of BHA per $\mathrm{g}$ of fat was added [31].

They were then cooked in forced convection oven (TecnoDalvo, SRL, Argentina), at $200^{\circ} \mathrm{C}$ for 15 minutes, until $72^{\circ} \mathrm{C}$ internal temperature (indicated by digital stem thermometer TPD 33, Omega Engineering, Inc., Connecticut, USA) was reached. Cooked patties were cooled at room temperature and vacuum-packed (Rapi-Vac $\mathrm{S}-750$ ) in polypropylene bags and kept at $4^{\circ} \mathrm{C}$ for further analysis at 0,8 and 15 days of storage.

Three independent trials were done. Each time three (3) burgers for type of treatment were prepared, for each storage time analyzed.

\subsection{Physicochemical Determinations}

\subsubsection{Fat Extraction}

The Bligh and Dyer method [32] was used for fat extraction from meat samples. The extraction procedure was briefly as described by Miranda et al. [20]: $4.5 \mathrm{ml}$ of chloroform were added to a $10 \mathrm{~g}$ sample followed by the addition of $10 \mathrm{ml}$ of methanol, and $10 \mu \mathrm{l}$ of an appropriate solution of BHA, and mixed for 3 minutes; then 6.5 $\mathrm{ml}$ of distilled water and $4.5 \mathrm{ml}$ chloroform were added. After decantation, the organic phase was isolated, collected in cap tubes and heated in a water bath $\left(50^{\circ} \mathrm{C}\right)$ and kept under nitrogenous flow for chloroform evaporation. The lipids obtained were kept at $-20^{\circ} \mathrm{C}$ until analysis.

\subsubsection{Fatty Acid Profile}

Boron trifluoride/methanolic solution (14\%) was used for fatty acid methyl esters preparation according to AOAC N $\mathrm{N}^{\circ} 969.33$ method. Fatty acid composition was determined by using a HP 6850 Gas chromatograph equipped with a Supelco 2340 capillary column (60 m length, $0.25 \mu \mathrm{m}$ internal diameter) and a FID detector. Standard methyl esters of fatty acids of $99 \%$ purity were used (FAME mix). The injector and detector temperature were $240^{\circ} \mathrm{C}$; the oven temperature was held at $140^{\circ} \mathrm{C}$ for $5 \mathrm{~min}$ and subsequently increased at $4{ }^{\circ} \mathrm{C} / \mathrm{min}$ to $240^{\circ} \mathrm{C}$ and kept at $240^{\circ} \mathrm{C}$ during $20 \mathrm{~min}$. Fatty acid composition of patties was obtained by comparing the rela- 
tive retention times of standards and expressed as relative percentage.

\subsubsection{Lipid Quality Indices}

Data obtained from fatty acid composition values of samples were used to calculate the nutritional ratios as PUFA/MUFA and n6/n3, and the Atherogenic index (AI) and Trombogenic index (TI) according to Zhang et al. [33], using Equations (1) and (2) as follows:

$$
\begin{gathered}
\mathrm{AI}=[(\mathrm{C} 12: 0)+(4 \times \mathrm{C} 14: 0)+(\mathrm{Cl} 6: 0)] \times[\mathrm{PUFA}(\mathrm{n} 6 \text { and } \mathrm{n} 3)+\mathrm{MUFA}]^{-1} \\
\mathrm{TI}=[(\mathrm{C} 14: 0)+(\mathrm{C} 16: 0)+(\mathrm{C} 18: 0)] \times[(0.5 \times \mathrm{MUFA})+(0.5 \times \mathrm{n} 6)+(3 \times \mathrm{n} 3)+(\mathrm{n} 3 \times \mathrm{n} 6-1)]^{-1}
\end{gathered}
$$

\subsubsection{Evolution of Oxidation Process}

Oxidation process was monitored by measuring Peroxide Value (PV) and Thiobarbituric Acid Reactive Substances (TBARS).

1) Peroxide Value (PV)

The ferric thiocyanate (FTC) method was adapted from the FIL-IDF method 74A:1991. Samples (0.02 $\mathrm{g}$ of extracted fat) dissolved in $9.8 \mathrm{ml}$ of methanol: chloroform (70:30) solution and $0.1 \mathrm{ml}$ of $30 \%(\mathrm{w} / \mathrm{v})$ ammonium thiocyanate were added and mixed. Precisely $5 \mathrm{~min}$ after the addition of $0.1 \mathrm{ml}$ of ferrous chloride $(3.5 \% \mathrm{v} / \mathrm{v}$ hydrochloride acid solution) to the reaction mixture, the absorbance of the resulting red colour was measured at $501 \mathrm{~nm}$ against solvent solution as blank. PV was expressed in terms of mili equivalent of oxygen per $\mathrm{kg}$ of sample ( $\mathrm{mEq} \mathrm{O}_{2} / \mathrm{kg}$ sample).

2) Thiobarbituric Acid Reactive Substances (TBARS)

TBARS were determined according to Sinnhuber and Yu [34] with slight modifications. Sample (100 $\mu \mathrm{g}$ of extracted fat) was placed in $10 \mathrm{ml}$ test tubes; then $10 \mu \mathrm{l}$ of BHA (appropriate ethanolic solution) and $2 \mathrm{ml}$ of TBA solution (20 mM TBA in 15\% TCA) were subsequently added. The mixture was vortexed and heated in a water bath $\left(90^{\circ} \mathrm{C}\right)$ for 15 minutes. After cooling at room temperature, $2 \mathrm{ml}$ of chloroform were added, followed by centrifugation at $650 \mathrm{~g}$ for 15 minutes. The absorbance of supernatant was read at $532 \mathrm{~nm}$ against a blank containing $0.1 \mathrm{ml}$ of distilled water and $2 \mathrm{ml}$ of TBA/TCA solution. Malondialdehyde (MDA) standard curve was prepared from different 1,1,3,3-tetramethoxypropane solutions, and TBARS were expressed as mg of MDA/kg dry matter.

3) Antioxidant activity

The antioxidant activity at the end of the assay time was expressed as inhibition percent of peroxidation (IP\%) and calculated according to Equation (3) for each indicator referred to a control without antioxidant (blank):

$$
\mathrm{IP} \%=\left[\frac{(\text { Peroxidation indicator value blank }- \text { Peroxidation indicator value sample })}{\text { Peroxidation indicator value blank }}\right] * 100
$$

The higher the IP, the higher the antioxidant activity.

\subsubsection{Hunter L*, a* and b* Values Colour}

Colour measurements were performed using an Evolution $600 \mathrm{UV}-\mathrm{Vis}$ (ThermoScentific) equipped with an integrated sphere with Visionlite Colour Calc Software (Germany) to obtain CIE L*, a* and $b^{*}$ values for the MRP and all beef patties. The American Meat Science Association Guidelines [35] for colour measurements were followed in order to calculate total colour change $(\Delta \mathrm{E})$ over a selected period of time:

$$
\Delta \mathrm{E}=\left[\left(\Delta \mathrm{L}^{*}\right) 2+\left(\Delta \mathrm{a}^{*}\right) 2+\left(\Delta \mathrm{b}^{*}\right) 2\right]^{1 / 2}
$$

\subsection{Statistical Analysis}

A 4 treatment $\times 3$ storage periods factorial design with three replicates was used. Data analysis was done with the ANOVA function using the software package Statgraphics Plus. Duncan's multiple range test $(p<0.05)$ was used to determine mean differences between treatment means. 


\section{Results and Discussion}

\subsection{Fatty acid Composition of Meat Patties}

Consumers are becoming more aware of the relationship between diet and health and this fact has increased their interest in the nutritional value of foods [36]. According to Morales et al. [37] healthy aspects are one of the relevant factors affecting consumers to purchase certified beef products. Thus, we focused on the analysis of beef patties fortified with beneficial fatty acid achieved through the modification of the lipid profile of the control (traditional patty). This in order to provide a healthier meat product in terms of indices which take into account different effects of fatty acids on cardiovascular risk, such as PUFA/SFA ratio, n6/n3 ratio, the Index of Atherogenicity (AI) and the Index of Thrombogenicity (TI).

Table 1 compares the most important aspects of the fatty acid profile of SO, TP and FP (cooked products). Fortified meat system contained approximately a 90\%more PUFA than the conventional product. A 2 -fold increment for $\alpha$-linolenic acid was observed in modified cooked product (1.74 vs 3.70$)$ as a consequence of the addition of soybean oil in relation to the control (TP). There was a strong increment in linoleic acid content (20.21 vs 35.14).These modifications were obviously reflected in nutritional ratios, the PUFA/SFA ratio increased from 0.62 in product without soybean oil to 1.47 in the modified one, and $\mathrm{n} 6 / \mathrm{n} 3$ ratio decreased for fortified meat products (11.6 to 9.5).

According to nutritional recommendations, fats having a low PUFA/SFA $(<0.4)$ and a high $\mathrm{n} 6 / \mathrm{n} 3(>5)$ ratio are considered unfavourable since they may induce an increase in cholesterolaemia. However, these two indexes are not totally adequate to evaluate the nutritional value of fats owing to the lack of information regarding MUFA. Therefore, the AI and TI are useful to a better approach to the nutritional evaluation of fats, since they are calculated on the basis of fatty acids with functional effects [38].

The improved lipid profile of beef patties contributed to decrease AI and TI, from 0.41 to 0.26 and 0.94 to 0.56 respectively. Variations in fatty acid profiles were similar to those described by Delgado-Pando, Cofrades, Ruiz-Capillas, and Jiménez-Colmenero [39] using healthier oil combination-in-water emulsions as pork back fat replacers in low-fat frankfurters, with improved PUFA/SFA and n6/n3 ratios compared to the control (1.7 to 0.27 and 9.27 to 0.47 respectively).

\subsection{Lipid Oxidation}

Data obtained from monitoring lipid oxidation showed that the PV of the sample without antioxidant (A) increased throughout the storage time, whereas $1 \%$ of MRP (B) inhibited the formation of peroxides only as from

\begin{tabular}{|c|c|c|c|}
\hline & TP & SO & FP \\
\hline$\Sigma$ SFA & $35.25 \pm 0.18^{\mathrm{c}}$ & $17.29 \pm 0.26^{\mathrm{a}}$ & $26.42 \pm 0.18^{\mathrm{b}}$ \\
\hline$\Sigma$ MUFA & $42.80 \pm 0.22^{\mathrm{c}}$ & $23.37 \pm 0.19^{\mathrm{a}}$ & $34.73 \pm 0.22^{\mathrm{b}}$ \\
\hline$\Sigma$ PUFA & $21.95 \pm 0.04^{\mathrm{a}}$ & $59.33 \pm 0.45^{\mathrm{c}}$ & $38.84 \pm 0.04^{\mathrm{b}}$ \\
\hline n3 & $01.74 \pm 0.03^{\mathrm{b}}$ & $07.74 \pm 0.07^{\mathrm{a}}$ & $03.70 \pm 0.03^{\mathrm{c}}$ \\
\hline n6 & $20.21 \pm 0.01^{\mathrm{a}}$ & $51.59 \pm 0.43^{\mathrm{c}}$ & $35.14 \pm 0.01^{\mathrm{b}}$ \\
\hline n9 & $39.96 \pm 0.14^{\mathrm{b}}$ & $23.70 \pm 0.38^{\mathrm{a}}$ & $32.91 \pm 0.14^{\mathrm{c}}$ \\
\hline PUFA/SFA & $00.62 \pm 0.00^{\mathrm{a}}$ & $03.43 \pm 0.05^{\mathrm{c}}$ & $01.47 \pm 0.01^{\mathrm{b}}$ \\
\hline $\mathrm{n} 6 / \mathrm{n} 3$ & $11.59 \pm 0.19^{c}$ & $06.66 \pm 0.14^{\mathrm{a}}$ & $09.50 \pm 0.07^{\mathrm{b}}$ \\
\hline AI & $00.42 \pm 0.00^{\mathrm{c}}$ & $00.19 \pm 0.00^{\mathrm{a}}$ & $00.27 \pm 0.00^{\mathrm{b}}$ \\
\hline $\mathrm{TI}$ & $00.94 \pm 0.01^{\mathrm{c}}$ & $00.01 \pm 0.00^{\mathrm{a}}$ & $00.56 \pm 0.00^{\mathrm{b}}$ \\
\hline
\end{tabular}

\footnotetext{
a, b, ${ }^{c}$ Means in a same line followed by a different letter are significantly different $(\mathrm{p}<0.05)$.
} 
seven days. PV of the sample with 3\% MRP (C) were lower than A and B during all the assayed time. Nevertheless, PV achieved at the end of the storage time for samples with 1\% MRP showed no significant difference with samples containing 3\% MRP (Figure 1).

Figure 2 shows that the development of TBARS in A samples ( $0 \%$ MRP) also increased throughout the storage, while $3 \%$ of MRP inhibited TBARS formation more efficiently than $1 \%$.

Lipid hydroperoxides are the primary oxidation products and, thus, a precursor for further decomposition into the volatile secondary oxidation products causing off-flavours in meat. According to Argentinean Food Code [31], the PVs of edible oils and fats should not exceed $10 \mathrm{mEq} \mathrm{O} / 2 \mathrm{~kg}$, while MDA concentration should not exceed $2 \mathrm{mg} / \mathrm{kg}$ since this is the cut value of rancidity perception by consumers as indicated by Karakaya \& Simsek [40]. In this regard PV values of $n 3$ fortified beef patties with 3\% MRP was kept under the limit level during all the storage time, whereas a higher oxidation in terms of TBARS was reached just at 9 days, which was considered as the maximum acceptable storage time.

Thus, PV and TBARS at 9 days of storage (values obtained from linear regression of the corresponding evolution graphs) were used to estimate the antioxidant activity for each indicator as inhibition percentage of peroxidation $(\% \mathrm{IP})$, comparing with the antioxidant effect of the synthetic antioxidant reference.

This can be seen in Figure 3, which shows that the MRP exerted an acceptable inhibition effect on both stages of lipid oxidation, since IP on hydroperoxides formation was higher than $70 \%$, whereas IP on TBARS was higher than $45 \%$, stating that the antioxidant action of the MRP was suitable in the first stages of the peroxidation (IP $=70 \%$ ), which was highly positive given the high content of PUFAs, with the highest inhibition on secondary oxidation products $(\mathrm{IP}=74 \%)$.

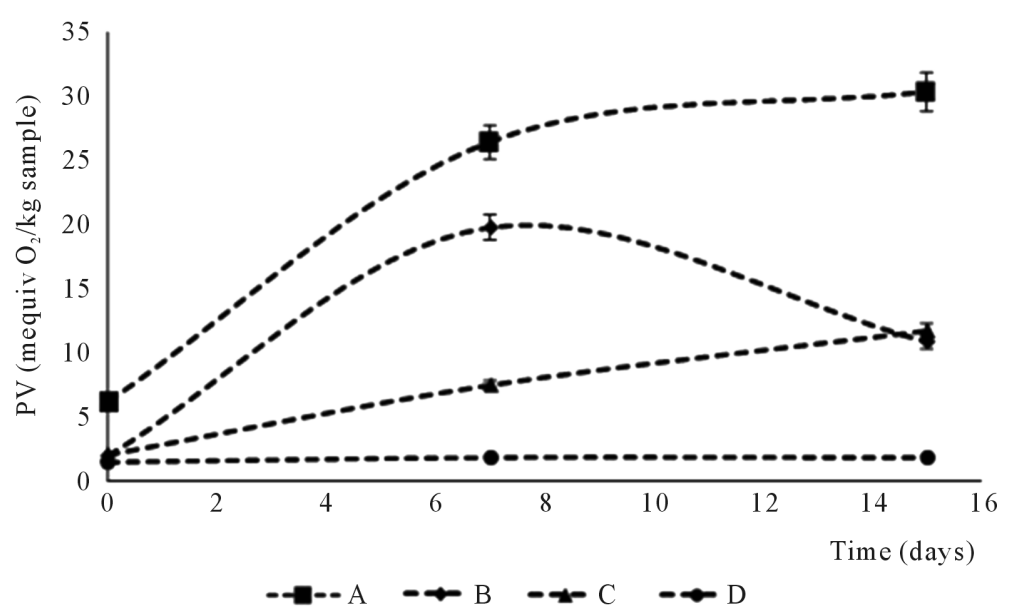

Figure 1. PV evolution during chilling storage of $n 3$ fortified beef patties added with A) $0 \%$ MRP; B) $1 \%$ MRP; C) $3 \%$ MRP and D) $0.01 \%$ BHA.

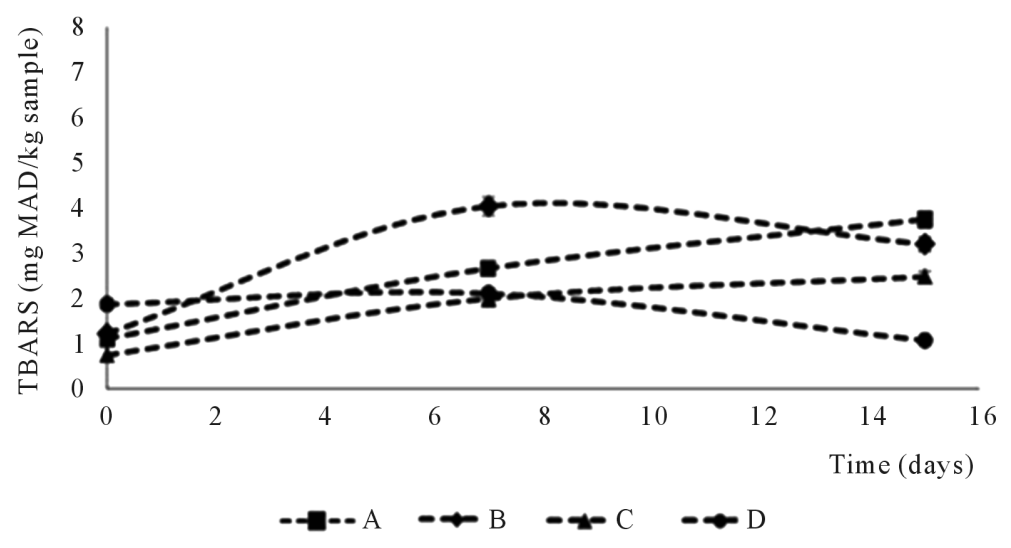

Figure 2. TBARS evolution during chilling storage of $\mathrm{n} 3$ fortified beef patties added with A) $0 \%$ MRP; B) $1 \%$ MRP; C) $3 \%$ MRP and D) $0.01 \%$ BHA. 


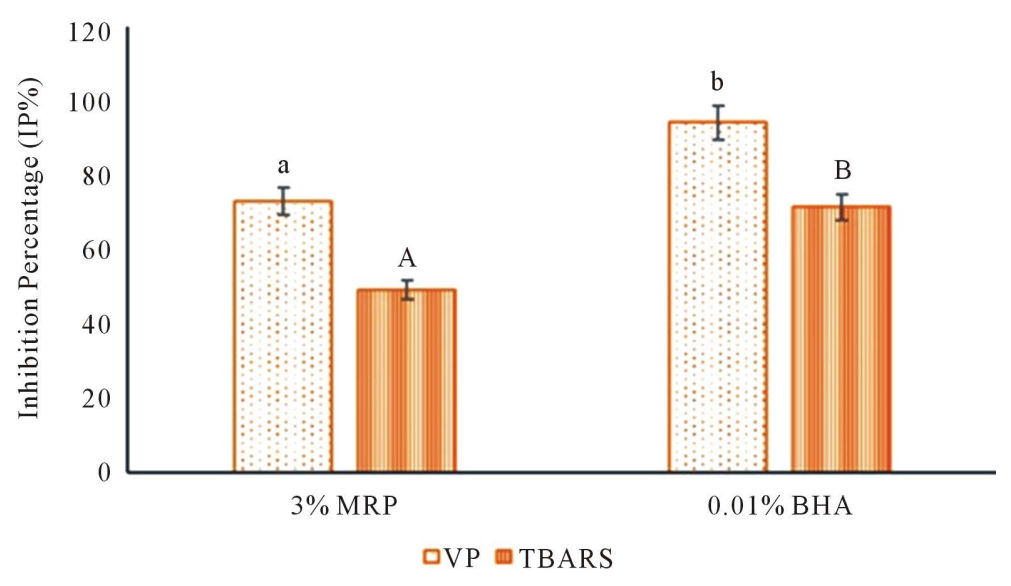

Figure 3. Inhibition percent on hydroperoxides (PV) and TBARS formation achieved in fortified meat patties added with $3 \%$ MRP and $0.01 \%$ BHA.

Fortified meat formulation is highly susceptible to lipid oxidation since it has a high PUFA content because of the $\mathrm{SO}$ added. This formulation was also prepared with salt $(2 \% \mathrm{NaCl})$ which is known to enhance pro oxidant activity in myofibrillar foods [41]. Moreover, some of the additives with antioxidant activity (for example, nitrites or ascorbic acid) commonly used in cooked meat processing were not included in the formulations so that the real MRP antioxidant effect could be measured. On the other hand, lipid oxidation in muscle foods is interrelated with myoglobin oxidation, and both reactions appear capable of influencing each other [42]. Myoglobin and other heme compounds in red meats act as catalysts resulting in the formation of metmyoglobin and $\mathrm{H}_{2} \mathrm{O}_{2}$ necessary to induce lipid peroxidation. Previous studies have demonstrated that the MRP under study had $71 \%$ of chelating activity [23] in model systems, which was attributed to the presence of hydroxyl and pyrrol groups [43] [44]. It has also been demonstrated that the MRP exhibited a high reducing power, related to the presence of reductones which have the ability to donate hydrogen atoms [45]. These two attributes of the MRP could explain its antioxidant action in the fortified meat assessed, since it acts as metal quelator and at the same time has a great ability to generate a reducing environment.

Two aspects of the antioxidant product must be highlighted: first, in this study the antioxidant effect was evaluated on cooked products subjected to chilled storage, while most of the reports about the effect of different MRPs refers to raw meat [20] [46] or raw meat products [47]-[49], both of them under freezing conditions, or model systems [50] [51]. Secondly, this product can be directly added to the formulation, with no requirement of a previous treatment with the natural antioxidants, such as immersion in a solution of them.

\section{3. $\mathrm{L}^{*}, \mathrm{a}^{*}$ and $\mathrm{b} *$ Determination}

Considering meat products, colour is the first attribute evaluated by consumers as an indicator of quality and freshness [52] [53]. In this regard, $\mathrm{L}^{*}, \mathrm{a}^{*}$ and $\mathrm{b}^{*}$ determinations were carried for fortified meat patties with and without antioxidants to evaluate changes in the colour of the final product.

The partial replacement of animal fat with soybean oil led to raw patties with higher $\mathrm{L}^{*}$ values $(51.90$ to 42.94), because small oil globules reflect more light than larger beef fat globules, as indicated by Youseff and Barbut [54].

The addition of the MRP seems to represent an extra protective effect against protein oxidation, since fortified patties with 3\% MRP showed the lowest decrease for $\mathrm{a}^{*}$ values compared to the control (28.24 to 28.34). This is concordant with Gañhao and others [55] who correlated the oxidation of beef proteins with the instrumental colour parameters, and different studies which noticed a protection action of MRPs against protein damage [42]. On the other hand, when $\Delta \mathrm{E}>3$ colour differences are obvious for the human eye [56]. In this sense, the colour differences were appreciative by the human eye only at $10^{\circ} \mathrm{C}$ and after 5 days of storage.

Given the high amounts of MRP added, no colour changes in the final product represented an important advantage in comparison with other frequent food antioxidants, which generally darken meat products. Different studies report this fact, i.e. Gibis \& Weiss [57] observed a significant decreased of L* value when grape seed and rosemary extract were added to beef patties, while Kim et al. [58] observed the same effect during the sto- 
rage of ground beef treated with rosemary extract.

However, this study does not consider the effect of other ingredients commonly used in the industry, suggesting the need to verify what happens in the presence of such substances. On the other hand, the results are limited to meat slaughter provided by the single available slaughterhouse in the area, which should be considered when repeating the study.

\section{Conclusions}

The manufacture of beef patties with soybean oil as a partial pork back fat replacer leads to products with enhanced nutritional properties as a result of a more favorable fatty acid profile. The addition of MRP clearly provides significant protection against lipid oxidation, being an attractive alternative to synthetic antioxidants for extending the shelf life of processed meat.

These results highlight remarkable technological applications of the MRP as a food ingredient in the design of healthier meat commodities, with the added value of being obtained from bovine blood, which renders a traditional waste of the meat industry. On the other hand, finding new applications for blood components represents an important challenge for scientists. Thus the development of procedures and applications that allow the utilization of animal blood on a larger scale will contribute both to eliminate a sizable pollution hazard and prevent the loss of potentially valuable material. This is particularly true in developing countries, where traditional sources of proteins and irons are either expensive or unavailable.

The accomplishment of further sensory, texture and microbiological analyses should confirm the extent of the impact on particular sensory features and on consumer's acceptance.

\section{Acknowledgements}

The authors would like to thank the members of Food Industry II Laboratory who contributed with their technical assistance and fruitful discussions.

This study was supported by the National University of Chaco Austral (UNCAUS) and the National Council of Scientific and Technical Investigations (CONICET).

\section{References}

[1] Biesalski, H.K. (2005) Meat as a Component of a Healthy Diet-Are There Any Risks or Benefits if Meat Is Avoided in the Diet? Meat Science, 70, 509-524. http://dx.doi.org/10.1016/j.meatsci.2004.07.017

[2] Sieri, S.V., Krogh, P., Ferrari, F., Berrino, V., Pala, A., Thiébaut, A., et al. (2008) Dietary Fat and Breast Cancer Risk in the European Prospective Investigation into Cancer and Nutrition. The American Journal of Clinical Nutrition, 88, 1304-1312.

[3] Siri-Tarino, P., Sun, Q., Hu, F. and Krauss, R. (2010) Saturated Fat, Carbohydrate, and Cardiovascular Disease. American Journal of Clinical Nutrition, 5, 502-509. http://dx.doi.org/10.3945/ajcn.2008.26285

[4] Gonzalez, C. and Riboli, E. (2010) Diet and Cancer Prevention: Contributions from the European Prospective Investigation into Cancer and Nutrition (EPIC) Study. European Journal of Cancer, 46, 2555-2562. http://dx.doi.org/10.1016/j.ejca.2010.07.025

[5] (2015) Animal Foods/World Cancer Research Fund International. http://www.wcrf.org/int/research-we-fund/cancer-prevention-recommendations/animal-foods

[6] Berasategi, I., Legarra, S., García-Íñiguez de Ciriano, M., Rehecho, S., Calvo, M., Cavero, R., et al. (2011) High in Omega-3 Fatty Acids' Bologna-Type Sausages Stabilized with an Aqueous-Ethanol Extract of Melissa Officinalis. Meat Science, 88, 705-711. http://dx.doi.org/10.1016/j.meatsci.2011.02.035

[7] Rodríguez-Carpena, J., Morcuende, D. and Estévez, M. (2012) Avocado, Sunflower and Olive Oils as Replacers of Pork Back-Fat in Burger Patties: Effect on Lipid Composition, Oxidative Stability and Quality Traits. Meat Science, 90, 106-115. http://dx.doi.org/10.1016/j.meatsci.2011.06.007

[8] Muguerza, E., Gimeno, O., Ansorena, D., Bloukas, J. and Astiasarán, I. (2001) Effect of Replacing Pork Backfat with Pre-Emulsified Olive Oil on Lipid Fraction and Sensory Quality of Chorizo de Pamplona-A Traditional Spanish Fermented Sausage. Meat Science, 59, 251-258. http://dx.doi.org/10.1016/S0309-1740(01)00075-4

[9] Choi, Y., Choi, J., Han, D., Kim, H., Lee, M., Jeong, J., et al. (2010) Effects of Replacing Pork Back Fat with Vegetable Oils and Rice Bran Fiber on the Quality of Reduced-Fat Frankfurters. Meat Science, 84, 557-563.

http://dx.doi.org/10.1016/j.meatsci.2009.10.012 
[10] Poyato, C., Ansorena, D., Berasategi, I., Navarro-Blasco, I. and Astiasarán, I. (2014) Optimization of a Gelled Emulsion Intended to Supply $\Omega-3$ Fatty Acids into Meat Products by Means of Response Surface Methodology. Meat Science, 98, 615-621. http://dx.doi.org/10.1016/j.meatsci.2014.06.016

[11] Romero, M., Garro, O., Romero, A., Michaluk, A., Doval, M. and Judis, M. (2014) Assessment of the Quality and Shelf-Life in Enriched n3 PUFA Raw Beef Patties Using Dry Soybean Sprouts as Antioxidant. Food and Nutrition Sciences, 5, 658-670. http://dx.doi.org/10.4236/fns.2014.57077

[12] Del Nobile, M., Conte, A., Incoronato, A., Panza, O., Sevi, A. and Marino, R. (2009) New Strategies for Reducing the Pork Back-Fat Content in Typical Italian Salami. Meat Science, 81, 263-269. http://dx.doi.org/10.1016/j.meatsci.2008.07.026

[13] Lee, S., Faustman, C., Djordjevic, D., Faraji, H. and Decker, E. (2006) Effect of Antioxidants on Stabilization of Meat Products Fortified with n-3 Fatty Acids. Meat Science, 72, 18-24. http://dx.doi.org/10.1016/j.meatsci.2005.05.022

[14] García-Iñiguez de Ciriano, M., Larequi, E., Rehecho, S., Calvo, M., Cavero, R., Navarro-Blasco, I., et al. (2010) Selenium, Iodine, Omega-3 PUFA and Natural Antioxidant from Melissa Officinalis L.: A Combination of Components from Healthier Dry Fermented Sausages Formulation. Meat Science, 85, 274-279. http://dx.doi.org/10.1016/j.meatsci.2010.01.012

[15] Silva, F., Borges, M. and Ferreira, M. (1999) Methods for Evaluating Lipid Oxidation Level and Antioxidant Capacity. Métodos Para Avaliacao Do Grau De Oxidacao Lipídica E Da Capacidade Antioxidante.Quimica Nova, 22, 94-103. http://dx.doi.org/10.1590/S0100-40421999000100016

[16] Naveena, B., Sen, A., Kingsly, R., Singh, D. and Kondaiah, N. (2008) Antioxidant Activity of Pomegranate Rind Powder Extract in Cooked Chicken Patties. International Journal of Food Science \& Technology, 43, 1807-1812. http://dx.doi.org/10.1111/j.1365-2621.2007.01708.x

[17] Rababah, T., Hettiarachchy, N. and Horax, R. (2004) Total Phenolics and Antioxidant Activities of Fenugreek, Green Tea, Black Tea, Grape Seed, Ginger, Rosemary, Gotu Kola, and Ginkgo Extracts, Vitamin E, And Tert-Butylhydroquinone. Journal of Agricultural and Food Chemistry, 52, 5183-5186. http://dx.doi.org/10.1021/jf049645z

[18] Selani, M., Contreras-Castillo, C., Shirahigue, L., Gallo, C., Plata-Oviedo, M. and Montes-Villanueva, N. (2011) Wine Industry Residues Extracts as Natural Antioxidants in Raw and Cooked Chicken Meat During Frozen Storage. Meat Science, 88, 397-403. http://dx.doi.org/10.1016/j.meatsci.2011.01.017

[19] Vhangani, L. and Van Wyk, J. (2013) Antioxidant Activity of Maillard Reaction Products (Mrps) Derived from Fructose-Lysine and Ribose-Lysine Model Systems. Food Chemistry, 137, 92-98. http://dx.doi.org/10.1016/j.foodchem.2012.09.030

[20] Miranda, L., Rakovski, C. and Were, L. (2012) Effect of Maillard Reaction Products on Oxidation Products in Ground Chicken Breast. Meat Science, 90, 352-360. http://dx.doi.org/10.1016/j.meatsci.2011.07.022

[21] Benjakul, S., Lertittikul, W. and Bauer, F. (2005) Antioxidant Activity of Maillard Reaction Products from a Porcine Plasma Protein-Sugar Model System. Food Chemistry, 93, 189-196. http://dx.doi.org/10.1016/i.foodchem.2004.10.019

[22] Fernandez, C., Sturla, M., Doval, M., Romero, A. and Judis, A. (2012) Inhibition of Lipid Oxidation by MRP Antioxidant in Enriched Cooked Beef Patties with Polyunsaturated Fatty Acids. Journal of Food Research, 1, 128-137. http://dx.doi.org/10.5539/jfr.v1n3p128

[23] Fernandez, C., Doval, M., Romero, A. and Judis, M. (2014) Maillard Reaction Product from Bovine Plasma Proteins as Antioxidant on Model Systems. International Journal of Applied Science and Technology, 4, 104-110.

[24] Del Hoyo, P., Rendueles, M. and Díaz, M. (2008) Effect of Processing on Functional Properties of Animal Blood Plasma. Meat Science, 78, 522-528. http://dx.doi.org/10.1016/j.meatsci.2007.07.024

[25] Jayathilakan, K., Sultana, K., Radhakrishna, K. and Bawa, A. (2012) Utilization of Byproducts and Waste Materials from Meat, Poultry and Fish Processing Industries: Areview. Journal of Food Science and Technology, 49, 278-293. http://dx.doi.org/10.1007/s13197-011-0290-7

[26] Di Bernardini, R., Harnedy, P., Bolton, D., Kerry, J., O’Neill, E., Mullen, A., et al. (2011) Antioxidant and Antimicrobial Peptidic Hydrolysates from Muscle Protein Sources and By-Products. Food Chemistry, 124, 1296-1307. http://dx.doi.org/10.1016/j.foodchem.2010.07.004

[27] Salgado, P., Fernández, G., Drago, S. and Mauri, A. (2011) Addition of Bovine Plasma Hydrolysates Improves the Antioxidant Properties of Soybean and Sunflower Protein-Based Films. Food Hydrocolloids, 25, 1433-1440. http://dx.doi.org/10.1016/j.foodhyd.2011.02.003

[28] Hartmann, R. and Meisel, H. (2007) Food-Derived Peptides with Biological Activity: from Research to Food Applications. Current Opinion in Biotechnology, 18, 163-169. http://dx.doi.org/10.1016/j.copbio.2007.01.013

[29] Robson, R., Goll, D. and Temple, M. (1968) Determination of Proteins in "Tris" Buffer by the Biuret Reaction. Analytical Biochemistry, 24, 339-341. http://dx.doi.org/10.1016/0003-2697(68)90188-7

[30] Fernandez, C., Romero, A., Doval, M., Sturla, M. and Judis, M. (2010) Influence of Meat Components on Antioxidant 
Activity of Beef Sarcoplasmic Proteins / Malondialdehyde Reaction Products in Model Emulsions. Electronic Journal of Environmental, Agricultural and Food Chemistry, 9, 636-645.

[31] ANMAT (2015) http://www.anmat.gov.ar/alimentos/normativas alimentos caa.asp

[32] Bligh, E. and Dyer, W. (1959) A Rapid Method of Total Lipid Extraction and Purification. Canadian Journal of Biochemistry and Physiology, 37, 911-917. http://dx.doi.org/10.1139/059-099

[33] Zhang, Z., Liu, L., Xie, C., Li, D., Xu, J., Zhang, M. and Zhang, M. (2014) Lipid Contents, Fatty Acid Profiles and Nutritional Quality of Nine Wild Caught Freshwater Fish Species of the Yangtze Basin, China. Journal of Food and Nutrition Research, 2, 388-394. http://dx.doi.org/10.12691/jfnr-2-7-10

[34] Sinnhuber, R. and Yu, T. (1977) The 2-Thiobarbituric Acid Reaction, An Objective Measure of the Oxidative Deterioration Occurring in Fats and Oils. Journal of Japan Society of Fish Science, 26, 259-267.

[35] AMS Association, AMSA Meat Color Measurement Guidelines (2012) http://www.meatscience.org/docs/default-source/publications-resources/Hot-Topics/download-the-ebook-format-pdf-of -the-meat-color-measurement-guidelines.pdf?sfvrsn $=0$

[36] Scollan, N., Hocquette, J., Nuernberg, K., Dannenberger, D., Richardson, I. and Moloney, A (2006) Innovations in Beef Production Systems that Enhance the Nutritional and Health Value of Beef Lipids and their Relationship with Meat Quality. Meat Science, 74, 17-33. http://dx.doi.org/10.1016/j.meatsci.2006.05.002

[37] Morales, L., Griffith, G., Wright, V., Fleming, E., Umberger, W. and Hoang, N. (2013) Variables Affecting the Propensity to Buy Branded Beef among Groups of Australian Beef Buyers. Meat Science, 94, 239-246. http://dx.doi.org/10.1016/j.meatsci.2013.02.005

[38] Ahmed, S., Islam, M., Bostami, R., Mun, H., Kim, Y. and Yang, C. (2015) Meat Composition, Fatty Acid Profile and Oxidative Stability of Meat from Broilers Supplemented with Pomegranate (Punica granatum L.) Byproducts. Food Chemistry, 188, 481-488. http://dx.doi.org/10.1016/j.foodchem.2015.04.140

[39] Delgado-Pando, G., Cofrades, S., Rodríguez-Salas, L. and Jiménez-Colmenero, F. (2011) A Healthier Oil Combination and Konjac Gel as Functional Ingredients in Low-Fat Pork Liver Pâté. Meat Science, 88, 241-248. http://dx.doi.org/10.1016/j.meatsci.2010.12.028

[40] Karakaya, S. and Şimșek, S. (2011) Changes in Total Polar Compounds, Peroxide Value, Total Phenols and Antioxidant Activity of Various Oils Used in Deep Fat Frying. Journal of the American Oil Chemists' Society, 88, 1361-1366. http://dx.doi.org/10.1007/s11746-011-1788-x

[41] Sánchez-Muniz, F., Canales, A., Nus, M., Bastida, S., Guillén, M., Corella, D., et al. (2012) The Antioxidant Status Response to Low-Fat and Walnut Paste-Enriched Meat Differs in Volunteers at High Cardiovascular Risk Carrying Different PON-1 Polymorphisms. Journal of the American College of Nutrition, 31, 194-205. http://dx.doi.org/10.1080/07315724.2012.10720027

[42] Ulbin-Figlewicz, N. and Jarmoluk, A. (2015) Effect of Low-Pressure Plasma Treatment on the Color and Oxidative Stability of Raw Pork During Refrigerated Storage. Food Science and Technology International, 22, 313-324.

[43] Gu, F., Kim, J., Abbas, S., Zhang, X.-M., Xia, S.-Q. and Chen, Z.-X. (2010) Structure and Antioxidant Activity of High Molecular Weight Maillard Reaction Products from Casein-Glucose. Food Chemistry, 120, 505-511. http://dx.doi.org/10.1016/i.foodchem.2009.10.044

[44] Hofmann, T. (1998) Studies on Melanoidin-Type Colorants Generated from the Maillard Reaction of Protein-Bound Lysine and Furan-2-Carboxaldehyde-Chemical Characterisation of a Red Coloured Domaine. Zeitschrift für Lebensmitteluntersuchung und -Forschung A, 206, 251-258. http://dx.doi.org/10.1007/s002170050253

[45] Amarowicz, R. (2009) Antioxidant Activity of Maillard Reaction Products. European Journal of Lipid Science and Technology, 111, 109-111. http://dx.doi.org/10.1002/ejlt.200900011

[46] Li, X., Shi, X., Jin, Y., Ding, F. and Du, Y. (2013) Controllable Antioxidative Xylan-Chitosan Maillard Reaction Products Used for Lipid Food Storage. Carbohydrate Polymers, 91, 428-433. http://dx.doi.org/10.1016/j.carbpol.2012.08.052

[47] Liu, F., Xu, Q., Dai, R. and Ni, Y. (2015) Effects of Natural Antioxidants on Colour Stability, Lipid Oxidation and Metmyoglobin Reducing Activity in Raw Beef Patties. Acta scientiarum polonorum Technologia alimentaria, 14, 3744. http://dx.doi.org/10.17306/J.AFS.2015.1.4

[48] Kim, H., Cadwallader, K., Kido, H. and Watanabe, Y. (2013) Effect of Addition of Commercial Rosemary Extracts on Potent Odorants in Cooked Beef. Meat Science, 94, 170-176. http://dx.doi.org/10.1016/j.meatsci.2013.01.005

[49] Movileanu, I., Núñez De González, M., Hafley, B., Miller, R. and Keeton, J. (2013) Comparison of Dried Plum Puree, Rosemary Extract, and BHA/BHT as Antioxidants in Irradiated Ground Beef Patties. International Journal of Food Science, 7, 1-7. http://dx.doi.org/10.1155/2013/360732

[50] Eric, K., Raymond, L., Huang, M., Cheserek, M., Hayat, K., Savio, N., et al. (2013) Sensory Attributes and Antioxi- 
dant Capacity of Maillard Reaction Products Derived from Xylose, Cysteine and Sunflower Protein Hydrolysate Model System. Food Research International, 54, 1437-1447. http://dx.doi.org/10.1016/j.foodres.2013.09.034

[51] Wang, W., Bao, Y. and Chen, Y. (2013) Characteristics and Antioxidant Activity of Water-Soluble Maillard Reaction Products from Interactions in a Whey Protein Isolate and Sugars System. Food Chemistry, 139, 355-361. http://dx.doi.org/10.1016/j.foodchem.2013.01.072

[52] Faustman, C. and Cassen, G. (1990) The Biochemical Basis for Discoloration in Fresh Meat: A Review. Journal of Muscle Foods, 1, 217-243. http://dx.doi.org/10.1111/j.1745-4573.1990.tb00366.x

[53] Glitsch, K. (2012) Consumer Perceptions of Fresh Meat Quality: Cross-National Comparison. British Food Journal, 102, 177-194. http://dx.doi.org/10.1108/00070700010332278

[54] Youssef, M. and Barbut, S. (2009) Effects of Protein Level and Fat/Oil on Emulsion Stability, Texture, Microstructure and Color of Meat Batters. Meat Science, 82, 228-233. http://dx.doi.org/10.1016/j.meatsci.2009.01.015

[55] Ganhão, R., Morcuende, D. and Estévez, M. (2010) Protein Oxidation in Emulsified Cooked Burger Patties with Added Fruit Extracts: Influence on Colour and Texture Deterioration During Chill Storage. Meat Science, 85, $402-409$. http://dx.doi.org/10.1016/j.meatsci.2010.02.008

[56] Olivera, D., Bambicha, R., Laporte, G., Cárdenas, F. and Mestorino, N. (2013) Kinetics of Colour and Texture Changes of Beef during Storage. Journal of Food Science and Technology, 50, 821-825. http://dx.doi.org/10.1007/s13197-012-0885-7

[57] Gibis, M. and Weiss, J. (2012) Antioxidant Capacity and Inhibitory Effect of Grape Seed and Rosemary Extract in Marinades on the Formation of Heterocyclic Amines in Fried Beef Patties. Food Chemistry, 134, 766-774. http://dx.doi.org/10.1016/i.foodchem.2012.02.179

[58] Kim, H., Choi, Y., Choi, J., Kim, H.Y., Hwang, K., Song, D., et al. (2013) Antioxidant Effects of Soy Sauce on Color Stability and Lipid Oxidation of Raw Beef Patties During Cold Storage. Meat Science, 95, 641-646. http://dx.doi.org/10.1016/j.meatsci.2013.06.006

\section{Submit or recommend next manuscript to SCIRP and we will provide best service for you:}

Accepting pre-submission inquiries through Email, Facebook, Linkedin, Twitter, etc A wide selection of journals (inclusive of 9 subjects, more than 200 journals)

Providing a 24-hour high-quality service

User-friendly online submission system

Fair and swift peer-review system

Efficient typesetting and proofreading procedure

Display of the result of downloads and visits, as well as the number of cited articles

Maximum dissemination of your research work

Submit your manuscript at: http://papersubmission.scirp.org/ 